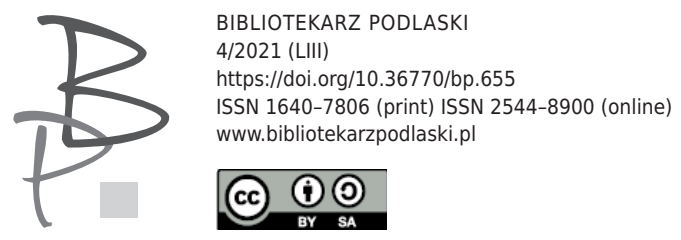

\title{
Marta Kowerko-Urbańczyk*
}

Uniwersytet w Białymstoku, Polska / University of Białystok, Poland

ORCID: 0000-0003-4325-2470

\section{Czesław Miłosz wobec przemocy i wojny}

[Rec. I. Grudzińska-Gross, Miłosz i długi cień wojny, nakładem wydawnictwa Pogranicze, Sejny 2020, ss. 191]

\section{Czesław Miłosz towards violence and war}

[rev. I. Grudzińska-Gross, Milosz and the Long Shadow of War,

Sejny 2020, 191 pgs.]

Abstract: This article reviews Irena Grudzińska-Gross's book Miłosz i długi cień wojny [Milosz and the Long Shadow of War], which was published by Pogranicze in 2020. The reviewer analyses the definition of violence and its relation to Polish narratives of wartime solidarity seen as heroism. To this end, she examines the work of Czesław Miłosz, written during the Second World War, and later texts thematising the war experience. An additional layer of the publication is the poet's take on the Jewish question - both in the context of Miłosz's poetic works and the subsequent discussions they provoked. The author, taking into account Miłosz's autobiogeographical predispositions, also analyses the changing images of Warsaw in his works as a space where the poet spent most of the war. For this reason, she

* Marta Kowerko-Urbańczyk - dr, pracuje na Wydziale Filologicznym Uniwersytetu w Białymstoku, autorka m.in. książki Wilno - Vilnius: polskie i litewskie reprezentacje miasta po roku 1990 (2016). 
examines the poet's attitude to the Warsaw Uprising and the public perception of his decision not to join the cause.

Keywords: Czesław Miłosz, Warsaw, Warsaw Uprising, Warsaw Ghetto Uprising, Jews.

Irena Grudzińska-Gross w książce Miłosz i długi cień wojny (2020) pisze o poecie w bardzo konkretnym momencie dziejowym i biograficznym, pytając o to, jak doświadczanie II wojny światowej sytuowało go wobec polskiej wspólnoty, w jaki sposób zapisywał je w tekstach i jak były one czytane przez kolejne pokolenia badaczy. Autorka wyznacza sobie trzy główne cele: rewiduje kwestię „wojskowego solidaryzmu”, który według jej rozpoznań dominuje w polskim dyskursie, oraz przygląda się kwestii żydowskiej w utworach Czesława Miłosza. W szerszym znaczeniu książka staje się manifestem przeciwko przemocy, przeciwko wyobrażeniom wojny obecnym w polskiej kulturze, które - jak to ujmuje sama autorka - „układają się w automatyczną siatkę skojarzeń: solidarność, braterstwo, czystość, poświęcenie, duma, czyn”. Jednocześnie upomina się o miejsce Żydów w polskim wojennym dyskursie, demonstrując, jak kwestia Holocaustu stawała się problematyczna dla badaczy.

Publikacja ma pięć rozdziałów, nierównomiernej długości, które funkcjonowały wcześniej jako osobne artykuły. Zamysł autorski jest dosyć czytelny, choć nie wszystkie redakcyjne decyzje bronią się w układzie książkowym: zdarzają się powtórzenia cytatów, powroty do interpretacji tych samych wierszy, tematyczne zakresy rozdziałów miejscami się nakładają i przenikają.

Pierwszy rozdział autorka poświęca przemocy, zarówno w uniwersalnym kontekście, jak i w perspektywie lektury Miłosza. Na podstawie powstałych w czasie wojny wierszy Grudzińska-Gross wyodrębnia trzy cele poety, które permanentnie powracają na późniejszych kartach jego twórczości. „Po pierwsze: nie poddać się rozpaczy; po drugie: starać się odgadnąć przyczyny triumfu zła”, oraz - po trzecie - znaleźć nowy język poetycki, by „nowa poezja - intelektualna i ironiczna - powinna być zdolna do stawiania czoła okrucieństwu i poczuciu absurdu"². Autorka zauważa, że zetknięcie z przemocą jest

1 Autorka sięga po cytaty z Traktatu poetyckiego. Cyt. za: Cz. Miłosz, Wiersze wszystkie, Kraków 2011, s. 412.

2 Tamże, s. 415. 
dla Miłosza jednym z fundamentalnych doświadczeń, choć referuje je dość pobieżnie: przywołuje jedynie wszystkożerność natury w Dolinie Issy, wiersz skierowany do Tadeusza Różewicza Unde malum czy Ziemię Ulro, ale nie poświęca temu zagadnieniu więcej miejsca.

Grudzińska-Gross proponuje kilka porządków, by zbadać doświadczenie przemocy: ciała doświadczającego bólu, figury matki i zagadnienia wiary. Poświęca im osobne podrozdziały. Pisząc o ciele, autorka (dość zaskakująco) sięga po wiersz Zbigniewa Herberta Apollo i Marsjasz (1961) jako jeden z najdoskonalszych zapisów fizycznego doświadczenia przemocy. Wprowadza tu liczne konteksty artystyczne i badawcze: okropności wojny, Francisca Goi, rozpoznania Elaine Scarry, Susan Sontag, przywołuje antropologiczną definicję zaproponowaną przez Joannę Tokarską-Bakir, według której siła i celowe poniżenie idą ze sobą w parze. Sygnalizuje w ten sposób niewyrażalność cielesnej empirii przemocy, które wiąże się z silnym przeświadczeniem, jak gdyby świat się właśnie kończył. Prowadzi ją to do zauważenia pewnych wybiegów, które w swojej wojennej twórczości stosował Miłosz. Pierwszym z nich jest wycofanie się w jak największą powściągliwość emocjonalną, co przejawia się w sięganiu do rozmaitych poetyk. Drugim - próba opisu przemocy, jak to ujmuje autorka, „bez patrzenia jej w oczy”, którą odnajdziemy w wierszu Biedny chrześcijanin patrzy na getto (1945), gdzie nagromadzenie powtórzeń przedstawia niszczenie ciał i rzeczy materialnych przez insekty ${ }^{3}$. Przemoc jest tu działaniem natury, wynika sponad ludzkiego porządku, a jednocześnie jej obrazy odsyłają do wizji pogromu lub szabrowania po pogromie.

Następnie autorka przygląda się figurze matki, którą Miłosz eksploatuje w wierszach: Ballada (1958), Przygotowanie (1984) i w powieści Zdobycie władzy (I wyd. pol. 1955). Ta perspektywa - kobiety, która w umierającym widzi (własne) dziecko, staje się uosobieniem cywilności, alternatywnym wobec świata męskich wojennych pryncypiów. Trzeci podrozdział podejmuje kwestię wiary. Mimo silnych związków z katolicyzmem, stanowiącego immanentną część tożsamości poety (w tym zabiegów o dokument potwierdzający jego religijną przynależność, który przed śmiercią pozyskał od Jana

3 Entomologiczną perspektywę u Miłosza znacznie szerzej zarysował Stefan Chwin, który śledząc przemiany tego motywu, widzi w nim dwie tendencje: arkadyjską (m.in. w Piosence o końcu świata) i katastroficzną (narastającą w wierszach wojennych). Por. S. Chwin, Dachau koników polnych, red. M. Zaleski, Warszawa 2013, s. 159-195. 
Pawła II), w Rodzinnej Europie (1958) mierzył się z mocno uwewnętrznionym przekonaniem o kolonizacyjnym charakterze wprowadzania chrześcijaństwa i przemocy zadawanej pogańskiej Litwie.

W drugim, najobszerniejszym rozdziale, zatytułowanym Cywil w okupowanej Warszawie, Irena Grudzińska-Gross sięga do metafory nożyc, wskazując, jak w sytuacji wojennej wyostrzają się przeciwieństwa (dobro-zło, nasz-obcy, honor-hańba, wierność-zdrada, żołnierz-cywil). Te skrajności kumulują się, spiętrzają, tworząc całe ciągi skojarzeń, a czasami nawet funkcjonują w ponadrzeczywistym poziomie, gdy śmierć może oznaczać bohaterstwo (choć realnie oznacza koniec pojedynczego istnienia). Jednocześnie - jak zauważa autorka - są nieprzystawalne do rzeczywistości, a już szczególnie nieadekwatne do opisów wojen z XX wieku z ogromną liczbą masowych, anonimowych i przypadkowych ofiar. Te wstępne rozważania eksplorowane są w następnych jedenastu podrozdziałach, które układają się w kilka tematycznych wątków: Warszawy i jej przestrzeni w twórczości poety, osobności Miłosza wobec polskich etnocentrycznych kategorii oraz jego sporów z młodszymi poetami „Sztuki i Narodu”, którzy zginęli podczas wojny: Tadeuszem Gajcym, Andrzejem Trzebińskim, Zdzisławem Stroińskim i Wacławem Bojarskim.

Grudzińska-Gross rozpoczyna od przyjrzenia się relacji, jaka łączyła poetę z Warszawą. Autorka tworzy tu biograficzne ramy tych związków i referuje, jak każdy z jego trzykrotnych pobytów w stolicy wiązał się z silnymi emocjami. W swoich rozważaniach eksponuje obcość i upokorzenie, doświadczane w wielu momentach i na wielu poziomach: w tym także głęboko odczuwane upokorzenie cywila. Następnie badaczka przygląda się wojennym obrazom stolicy: ulicy Tamka i przedmieściom, zauważając, jak niekonkretne, nieprecyzyjne, $\mathrm{z}$ gruntu niechętne są opisy tych miejsc $\mathrm{w}$ porównaniu z pieczołowitością obrazów Wilna czy nawet nie tak dobrze poecie znanego Paryża. Ulica ta powraca w Traktacie poetyckim (1957) jako przestrzeń ostatniej nocy tuż przed wybuchem wojny, pięknej i cichej, co autorka zestawia z późniejszym, kalifornijskim wierszem Dar (1971), utrzymanym w podobnym, niemal epifanijnym nastroju. Ale to peryferie, gdzie Miłosz mieszkał w późniejszych latach, doczekały się wyrazistszych, pełniejszych obrazów, zapisanych w wierszach Przedmieście i Na skraju Warszawy (1943).

Autorka sięga po komentarze do Przedmieścia wcześniejszych badaczy: Michała Głowińskiego i Aleksandry Okopień-Sławińskiej, pytając o to, dla- 
czego unikają nazwania wprost żydowskiego kontekstu. Kwestia żydowska zostaje przez nich dostrzeżona, ale potraktowana wymijająco ${ }^{4}$. Autorka polemicznie komentuje tę interpretacyjną praktykę. Jednocześnie teza, którą stawia Grudzińska-Gross, nie jest do końca czytelna - badaczka nie definiuje, co według niej oznacza ta autocenzura. Ponadto zauważa, że sam Miłosz również milczał na temat żydowskiego wątku Przedmieścia, a autokomentarz, który przytacza, nie jest do końca adekwatny - dotyczy wiersza Campo di Fiori (1943). Wątek ten uzupełnia głosami innych badaczy eksplorujących tematy żydowskie w całej twórczości poety. Obok obserwacji Piotra Matywieckiego, dowodzącego, że teza o banalności zła Hannah Arendt wybrzmiała już wcześniej w twórczości Miłosza, pojawia się także zarzut krytyczny wobec noblisty autorstwa Jacka Trznadla, który w Traktacie poetyckim dostrzega wyłącznie tragizm Żydów, nie zaś - jak chciałby badacz - powstania warszawskiego.

Następnie autorka powraca do reprezentacji Warszawy jako obojętnej wobec zła i Zagłady. Analizując skomplikowany stosunek do stolicy, zwraca uwagę na osobisty kontekst - warszawskie wojenne lata Miłosza to czas płodności artystycznej, zawierania przyjaźni i przeżywania miłości. Wszystko to - jej zdaniem - sprawiało, że zwłaszcza wczesne wiersze wojenne artysty cechują się jeszcze pewną ambiwalencją: „najpiękniejsze z urojonych miast i najsmutniejsze z prawdziwych", czułością, smutkiem oraz ironią zarazem. Ta wizja ewoluuje, po 1943 roku ocena stolicy jest już wyłącznie negatywna.

Na tle tych rozważań o zmieniającej się perspektywie Miłosza autorka podejmuje rozwijaną wcześniej metaforę nożyc. Dostrzega, jak Miłosz wystrzegał się tej klarownej binarności, wybierając dystans wobec kultu polskości jako odpowiedzi na niemiecki nacjonalizm. Przypominając tezę Miłosza, że Litwini to naród filologiczny, nazywa poetę „Polakiem filologicznym”, czyli takim, który o przynależności narodowej nie myśli w etnicznych kategoriach. Najpełniej zamanifestowało się to właśnie podczas wojny, w krytycznym stosunku do solidaryzmu wojennego, w rezygnacji z maszerowania w szeregu.

W podrozdziale Polegli $i$ zabici autorka przygląda się stosunkowi Miłosza do śmierci podczas wojny. Z jednej strony - przywołuje Żydów, któ-

4 „Nie trzeba wielkiej dociekliwości, o jakich wagonach mowa”, pisze Głowiński, a Okopień-Sławińska: „Strofę zamyka oczywisty zapis okupacyjnego doświadczenia”. Cyt. za: I. Grudzińska-Gross, Miłosz i dlugi cień wojny, Sejny 2020, s. 38-39. 
rym pomagał poeta. $Z$ drugiej - przygląda się napięciu, które wytworzyło się pomiędzy pojęciami: zabity/poległy/żywy w kontekście biografii Miłosza i młodszych od niego poetów, którzy zginęli w powstaniu warszawskim. Czytając biografię noblisty, napisaną przez Andrzeja Franaszka, znajduje w ustępie im poświęconym podniosłość wojennej terminologii (choć Franaszek stara się subtelnie kwestionować sens powstania). Te śmierci sytuują Miłosza na linii polegli-żywi, a nie zabici-żywi. Grudzińska-Gross formułuje tezę, że zadaniem żywych jest ochrona czci tych, co polegli i to jedna z nieprzekraczalnych granic narracji o wojnie, a jednocześnie nie dotyczy to Żydów, i poległych w walkach zbrojnych, i zabitych w Holocauście.

Kontynuując tę myśl, referuje, w jaki sposób badacze zastanawiają się, czy Miłosz musiał iść do powstania. W tym celu czyta zarówno biografię poety Franaszka, jak i towarzyszące jej wywiady. Zauważa, że o ile w książce biograf stroni od oskarżeń oraz usprawiedliwień, o tyle w wywiadach używa całej siatki pojęć heroicznych: wierność, przyjaźń, bohaterstwo, solidarność, które są niestopniowalne, przeciwstawione są przeczekiwaniu w piwnicy i byciu na tyłach.

Następnie autorka przywołuje spór (o) poetów „Sztuki i Narodu”, do którego często wraca w dalszych partiach książki. Jednocześnie nie referuje go, przytacza dość szczątkowo, wybiórczo . Wspiera się opinią Pawła Rodaka (,w manifestach literackich bezwzględni i buńczuczni, w poezji osamotnieni i słabi”) różnicującego twórczość poetycką Tadeusza Gajcego, Zdzisława Stroińskiego, Andrzeja Trzebińskiego i Wacława Bojarskiego od ich publicystyki i pieśni żołnierskich, które sławiły to, co Miłosz uznawał za zgubne - potęgę słowiańską, kulturę imperialną.

Badaczka pyta, czy charakter tej różnicy miał specyfikę pokoleniową. Nie wspomina, że młodsi od Miłosza poeci szanowali go za katastrofizm Trzech zim (1936), omawia natomiast, jak inaczej definiowali wspólnotowe obowiązki. Miłosz w późniejszej twórczości wracał do nich wielokrotnie, w tych powrotach Grudzińska-Gross widzi ból i irytację. I jednocześnie za

5 Jest to o tyle ciekawe, że Miłosz wchodził w różne spory z poszczególnymi poetami, zwłaszcza Andrzejem Trzebińskim i Tadeuszem Gajcym. W książce Ireny Grudzińskiej-Gross występują w jednym, powtarzającym się ciągu nazwisk, autorka nie różnicuje tych sporów. Por. S. Chwin, Dachau koników polnych, dz. cyt. oraz S. Bereś, T. Gajcy. W pierścieniu śmierci, Wołowiec 2016. 
Krzysztofem Rutkowskim przytacza dwie różne postawy wobec wojny zakodowane w europejskiej kulturze: Ulissesa, wybierającego rozum i Achillesa, decydującego się na poświęcenie, widząc w decyzjach Miłosza paradygmat Ulissesa, a młodszych o pokolenie poetów „Sztuki i Narodu” - Achillesa.

Rozdział jest rozległy, długi, niejednorodny. Początkowo bardzo ciekawie autorka zarysowuje jego zakres - ramy biograficzne związków Miłosza ze stolicą oraz zmieniające się w jego tekstach reprezentacje miasta. To perspektywa, która wykorzystuje bogatą Miłoszową pamięć autobio-geograficzną i autorka czyni to przekonująco, zestawiając z obrazami Wilna czy Paryża. Wywód trochę traci na klarowności i mocy, gdy autorka rozszerza swoje refleksje na stosunek poety do powstania warszawskiego (eksploruje również ten temat $\mathrm{w}$ następnych partiach książki). Podobnie ma się rzecz z komentarzami do Przedmieścia, gdy omówienia wierszy z tomu Ocalenie (1945) w kontekście milczenia powracają w jednej z następnych części.

W rozdziale Powstanie i siła poległych autorka odrywa się od Miłosza i koncentruje się wokół narracji historycznych opierających się na wzmożeniu patriotycznym i kulcie powstania warszawskiego. Publicystyczna teza Grudzińskiej-Gross sprowadza się do poglądu, że pytanie o sensowność zrywu jest kwestionowane, a mówienie o poświęceniu normatywne - bohaterska śmierć ustawiana jest w centralnym punkcie tej narracji. Widzi wielopoziomowe ramy zbudowane dla powstania: od Muzeum, poprzez pomniki, zmianę programów szkolnych i upowszechnianie świadectw uczestników. Zauważa, że nie można podjąć dyskusji z postawami Polaków w czasie wojny: z decyzją o powstaniu, o zachowaniu wobec Żydów, bez pytania: a co ty byś zrobił w sytuacji zagrożenia? Pytanie to, zdaniem autorki, kończy rozmowę, pozbawia szans na rzeczowe argumenty.

Tezy publicystyczne są efektowne, choć nie do końca precyzyjne - autorka formułuje je trochę uznaniowo, niedokładnie osadzając je w czasie: Muzeum Powstania zostało utworzone w 2004 roku. Przez te lata pojawiło się wiele prac kwestionujących jego sens i teza o braku zasadności zrywu istniała już w przestrzeni publicznej. Są one jej jednak potrzebne, by - ponownie - zapytać, jak współcześnie wygląda komentowanie decyzji Miłosza o nieuczestniczeniu w powstaniu. W tym celu sięga po tekst Stanisława Beresia wygłoszony na konferencji w 2011 roku, w którym badacz formułuje stanowisko, że atak Miłosza na środowisko „Sztuki i Narodu” związany był 
$\mathrm{z}$ „zapiekłą nienawiścią do prawicy” lub, co wydaje się Beresiowi bardziej prawdopodobne, $\mathrm{z}$,przeprojektowaniem, mającym uwolnić go od kompleksu powstańca". Grudzińska-Gross polemizuje ze stanowiskiem Beresia, który w tym konkretnym wystąpieniu - zdaniem autorki - „pomniejsza antysemityzm bohatersko poległych" ${ }^{1} \mathrm{i}$ oddaje głos Miłoszowi, który - jak sugeruje autorka - wypowiadał się na temat poglądów poetów jasno i wielowymiarowo, zarówno w publicystyce, jak i poezji.

Doprecyzowując stanowisko poety, autorka ponownie zwraca się ku Herbertowi. Rysując oś podziału pomiędzy Herbertowskim „Bądź wierny/ Idź” a Miłoszowym odrzuceniem „przymusu polskiej prawowierności”, przedstawia autora Trzech zim jako poetę, który ponad poczucie narodowej wspólnoty stawiał każdorazowy namysł i indywidualną ocenę sytuacji. Określa tę postawę jako mniejszościową, podlegającą presji moralnej, związaną z przymusem solidarności i zobowiązaniem do współwalki oraz przytacza słowa Miłosza, który mówił, że śmierć zamienia się w kapitał moralny. Autorka dopowiada, że ten kapitał dotyczy tylko Polaków, nie Żydów, poległych i zabitych.

U genezy osobnego głosu Miłosza, Grudzińska-Gross znajduje przyjaźnie czasów wojennych z ludźmi, którzy również uchylali się od zbrojnej walki (Kazimierz Wyka, Jerzy Andrzejewski, Tadeusz i Irena Krońscy), związek z Janiną Dłuską-Cękalską, późniejszą żoną. Kontestacja Miłosza ma również - a może przede wszystkim - charakter literacki, uwaga pozostaje tu przy żywych i umierających, niemal nie ma w jego poezji okupantów. Wszystko to składa się na polemiczny charakter tekstów Miłosza, polemiczny wobec stereotypu polskiego mężczyzny, gotowego poświęcić życie za Polskę, a co za tym idzie - gotowego użyć przemocy.

Zakończenie rozdziału precyzyjniej podsumowuje jego zakres niż zarysowywał to wstęp. Autorka skupia się na wojennych wyborach Miłosza, bo w nich przecinają się podstawowe wątki myślenia o Polsce. Naprzeciw Miłosza stawia kilka głosów wojennych, powojennych i zupełnie współczesnych narracji: poetów „Sztuki i Narodu”, Zbigniewa Herberta z jego słynnymi

6 I. Grudzińska-Gross, dz. cyt. s. 75-76. Cytaty pochodzą z tekstu: S. Bereś, Cień konspiracji, [w:] Miłosz i Miłosz, red. A. Fiut, A. Grabowski, Ł. Tischner, Kraków 2013, s. 403-433.

7 Tamże, s. 79. 
poetyckimi frazami, Stanisława Beresia, a wojenny solidaryzm konfrontuje z odmową uczestnictwa w zamkniętym kole przemocy.

Tytuł kolejnego rozdziału: Mówię do ciebie, milczac, pochodzi z wiersza Przedmowa z tomu Ocalenie z 1945 roku. Miłosz w wywiadach i eseistyce wielokrotnie nazywał 1943 rok mianem przełomowego ${ }^{8}$. Autorka nie ma zbyt wielu przesłanek, by wiązać to z tragedią Żydów w Warszawie, choć takie sugestie pobrzmiewają w tekście (po chwili Grudzińska-Gross je prostuje). Wprowadza tu perspektywę niewyrażalności doświadczenia wojennego, która przewija się przez cały rozdział - sytuując Miłosza w kontrapunkcie do nisko przez niego cenionej poezji wojennej.

Badaczka poświęca jednak głównie uwagę dwóm wierszom: Campo di Fiori i Biedny chrześcijanin patrzy na getto. Czytając pierwszy z nich, dostrzec możemy konkretną, dobrze znaną sytuację powstania wiersza: gdy Miłosz zobaczył jednocześnie dwa plany - ludzi walczących w getcie i po drugiej stronie - bawiących się na karuzeli, świętujących w ten sposób koniec Wielkiego Tygodnia. Stanowi to punkt wyjścia dla dwóch porządków interpretacji. Pierwszy znich dotyczy kwestii niewyrażalności Zagłady, a zarazem eksponuje samotność i doniosłość każdej śmierci. Drugi porządek można by nazwać faktograficznym. Sięga tu po inne świadectwa Miłosza, w których powracał temat karuzeli, a także przywołuje całą, blisko 80-letnią dyskusję na ten temat - czy karuzela tam stała, czy nie; w jakim momencie i kto ją postawił; czy bawiło się na niej dużo ludzi, czy nie. Tym spostrzeżeniom towarzyszy tutaj podsumowująca dyskusję gorzka konstatacja Justyny Kowalskiej-Leder, w myśl której debata poświęcona obojętności, utonęła w szczegółach i sama stała się jej manifestacją9.

Omówienie wiersza Biedny chrześcijanin patrzy na getto Grudzińska-Gross rozpoczyna od przyjrzenia się podwójności jego planów. Przywołuje bowiem dyskusję, którą od tego liryku rozpoczął w 1987 roku Jan Błoński, określając postawę Polaków jako „współwinę przez obojętność”, wyczytując z niego

8 Dość precyzyjnie możemy wskazać, z czym był związany ten przełom: wiązał się z bliższą znajomością z Tadeuszem Krońskim, który pozwolił mu wyzwolić się z - jak pisze Miłosz w Rodzinnej Europie - ,jakiejś mazi” patriotyczno-sentymentalnej, a jednak autorka pomija w tym miejscu ten wątek, wraca do niego dopiero pod koniec książki.

9 Cyt za: I. Grudzińska-Gross, dz. cyt., s. 112. Teza pojawiła się w debacie po obchodach 50. rocznicy powstania i znalazła się w tekście J. Kowalskiej-Leder, Mur, [w:] Ślady Holocaustu w imanginarium kultury polskiej, Warszawa 2017. 
świadectwo i wyzwanie, a może również oskarżenie. Barbara Shallcross nazwała utwór „etycznie radykalnym”"10, akcentując - zgodnie z intencją Miłosza, wielokrotnie wyrażaną w wywiadach - winę skierowaną na siebie. Tak czytana jednostkowa odpowiedzialność ,ja”, według Grudzińskiej-Gross, niesie ograniczenie, zawęża jego siłę rażenia, choć z perspektywy dzisiejszej wiedzy nie tylko o bierność w stosunku do Żydów chodzi, ale i o współwinę. O niej zresztą Miłosz - mimo wiedzy, którą na ten temat miał - nie lubił mówić. Grudzińska-Gross za Agnieszką Kosińską, asystentką noblisty, przywołuje sceptyczny stosunek Miłosza do sprawy Jedwabnego, który w prywatnych rozmowach zarzucał Janowi Grossowi wyjęcie tematu z kontekstu i uprawianie namiętności zamiast nauki.

Na marginesie tych rozważań autorka wprowadza też własną badawczą perspektywę - przytacza kontrowersje wokół prac Jana Grossa: wspomnianych Sasiadów (2000) i Strachu (2008) dotyczącego pogromu kieleckiego oraz wspólnie z nim napisanej książki Złote żniwa (2008) i polemizuje ze stanowiskiem Miłosza. Wszystko to prowadzi ją do nazwania współczesnych problemów z antysemityzmem. Wedle jej rozpoznań jest on w społecznym odbiorze postawą wyciszaną, nienazywaną wprost, mimo że wciąż intensywnie obecną, a historycznie znacznie bardziej powszechną niż pomaganie Żydom podczas wojny. Nie dyskutując z publicystyczną diagnozą Grudzińskiej-Gross, trudno oprzeć się wrażeniu, że zaangażowana osobista interpretacja miejscami przekracza intencje Miłosza. Poeta zresztą pojawia się tu właśnie w stanie niezadowolenia - znużony dyskusją na temat kontrowersji wokół karuzeli i niechętny do odczytywania Campo di Fiori na spotkaniach autorskich; unikający napisania oficjalnego komentarza do sprawy Jedwabnego; nieskłonny do komentowania Biednego chrześcijanina w późnych wywiadach.

Wobec tych wszystkich wyjętych z tekstu Grudzińskiej-Gross, a przecież obecnych w spuściźnie Miłosza, obiekcji i uników słabnie trochę jej teza o niewyrażalności doświadczenia Zagłady wpisanej w twórczość noblisty. W przytoczonych utworach Miłosz wyraża swoje bycie pomiędzy - pomiędzy ofiarami a bawiącym się thumem, a jednak po stronie tłumu, z poczuciem winy i samooskarżeniem. Pozostaje wątpliwość, czy Miłosz zmęczony polemikami unikał tej rozmowy czy może raczej faktycznie interesowała go bardziej analiza ,ja” wobec współwiny niż analiza polskiej zbiorowości. Z zebranych cytatów wy- 
nika raczej, że opowieść o Zagładzie nie była, by posłużyć się jego własnymi słowami, namiętnością noblisty, pozostając zarazem perspektywą autorki.

Ostatni rozdział poświęcony jest Simone Weil czytanej przez Miłosza. Grudzińska-Gross referuje ich równoległe, choć krańcowo odmienne życiorysy: młoda, przedwcześnie zmarła nie doczekała się publikacji swoich dzieł. W 1958 roku Miłosz przetłumaczył wybór jej tekstów na język polski. Autorka bada fascynacje przyszłego noblisty francuską filozofką: jej wrażliwością społeczną, solidarnością z pokrzywdzonymi, a także paradoksalnością jej wniosków, co było szczególnie bliskie Miłoszowi. Najbardziej jednak imponował mu jej manicheizm, który nierzadko wiązał się z bardzo radykalną postawą moralną oraz ponawianiem wciąż pytania o istotę zła (z łac. unde malum).

Dla Grudzińskiej-Gross najważniejsze jednak są rozważania Simone Weil o przemocy, które wyznaczają dwa nurty myślenia o jej konsekwencjach. Francuska myślicielka pisała między innymi, że każdy rodząc się, z góry jest skazany na doświadczenie przemocy, oraz że siła zastosowana przez ludzi zamienia ich w rzecz. Na antypodach jej stanowiska sytuuje się Hannah Arendt, która, cytując Frantza Fanona, pisze, że „uprawianie przemocy wiąże ludzi w jedną całość, bo każdy z nich staje się częścią jednego organizmu przemocy, który wzrasta". Sprawia to, że indywidualizm jest pierwszą rzeczą, która zanika, w zamian - jak rozwija myśl Arendt - „za rozwój intensywnej spójności grupowej, silniejszej niż przyjaźń, ale dużo mniej trwałej”. Filozofka postuluje, by starać się zastępować gwałt niegwałtownością, co rezonuje z odpowiedzią Miłosza.

W ten sposób kobieca perspektywa otwiera i zamyka książkę, stanowiąc dla niej swoistą ramę. W początkowych rozważaniach o przemocy Grudzińska-Gross przywołuje głównie badaczki, filozofki kończą zaś jej opowieść. Stanowią one znaczący kontekst wobec twórczości Miłosza i alternatywę względem dyskursywnej męskiej narracji o wojnie jako przestrzeni „wojskowego solidaryzmu", z którą przez całą książkę polemizuje autorka.

Książkę uzupełnia jeszcze posłowie Postscriptum do epizodu Joanny Tokarskiej-Bakir, w którym badaczka referuje spór pomiędzy Janem Józefem Szczepańskim a Czesławem Miłoszem, który miał miejsce w noc sylwestrową 1944/1945 i znalazł swoją literacką reprezentację w opowiadaniu Koniec legendy. Szczepański zjadliwie przedstawia w nim poetę Wielgosza, wyposażając go w poglądy Miłosza na temat powstania. Tokarska-Bakir szczegółowo bada tło tego opowiadania, przyglądając się tekstom wspomnieniowym Szcze- 
pańskiego dotyczącym dorastania w międzywojennej Polsce, zestawiając je ze wspomnieniami jego żydowskich rówieśników. Pozwala to jej dostrzec pewien rodzaj wyparcia antysemityzmu nieuświadomionego w latach 30 . ubiegłego stulecia, długo niedostrzegalnego z uprzywilejowanej perspektywy polskiego młodzieńca. Partyzancką kartę życiorysu Szczepańskiego podczas wojny konfrontuje ze świadectwami o Żydach mordowanych przez oddział, którego pisarz był członkiem. W ten sposób pojawia się pytanie o istnienie tabu w polskiej narracji bohaterskiej, a posłowie dodatkowo oświetla postawę samego Miłosza.

Próba redefinicji myślenia o wojnie przy użyciu ponadnarodowej, uniwersalnej kategorii przemocy jest ogromną poznawczą zaletą publikacji Grudzińskiej-Gross. Bohater, którego autorka wybiera, dostarcza jej ogrom źródłowego materiału: obok poezji, prozy, publicystyki, licznych autokomentarzy i wywiadów, pojawiają się również artykuły i teksty kilku pokoleń badaczy. Spuścizna Miłosza doskonale daje się odczytywać w kilku wybranych przez autorkę perspektywach. Pierwszą z nich byłaby autobiogeograficzna przestrzeń Warszawy, druga dotyczyłaby wchodzenia w intensywne spory z polskością, trzecia z kolei uchwycenia obojętności wobec tragedii Żydów. Tu Grudzińska-Gross czyta Miłosza blisko jego tekstów, w interesujących partiach przygląda się narracjom kilku pokoleń badaczy, wybierając szeroką reprezentację głosów, wśród których są $i$ te przychylne, i te nieprzychylne poecie.

Wątki żydowskie wprowadzone do książki przynoszą rekonesans sporów o obojętność Polaków wobec Zagłady. Autorka sięga tu do najważniejszych wierszy Miłosza, przypomina również te rzadziej interpretowane. A jednocześnie są to miejsca, w których autorka niekiedy zdaje się czytać Miłosza niejako ponad jego tekstem, chciałaby wyczytać z nich więcej niż sam autor był gotów odsłonić, a przede wszystkim - uczynić go stroną w sporze, od którego chciał się w późnych komentarzach uchylić.

Dodatkowym kontekstem tego zastrzeżenia jest szerszy stosunek Miłosza do kultury żydowskiej nieuwzględniony w książce, niejednorodny i skomplikowany. Poeta wielokrotnie podkreślał, że w międzywojniu polska i żydowska społeczność żyły równolegle, kompletnie się nie znając, lecz jak trafnie zauważa Karolina Szymaniak ${ }^{11}$, czyni to z dominującej pozycji (bo z perspek-

11 K. Szymaniak, Niezbyt łatwe miasto. Jidyszowa Warszawa (nie)widziana przez Miłosza, [w:] Warszawa Miłosza, red. M. Zaleski, Warszawa 2013, s. 85-104. 
tywy pisarzy jidysz, którzy szukali kontaktu z polskimi twórcami wyglądało to inaczej). Badaczka wymienia przy tym inne po wielokroć przez Miłosza powielane opinie: umniejszanie roli Warszawy jako żydowskiego centrum czy nie do końca uświadomioną orientalizację opisów żydowskich przestrzeni miast, powielaną nawet w późnych tekstach. I jednocześnie zauważa, jak Miłosz deklaratywnie, zachęcając do tego innych badaczy i edukatorów, starał się tę lukę uzupełnić, choć niekoniecznie swoim piórem.

Pozostaje więc Miłosz dla Grudzińskiej-Gross bohaterem doskonałym, gdy mówi o wojennej przestrzeni Warszawy, potyczkach z polskością, osobności, i jest nieidealny, gdy prawi o polsko-żydowskich relacjach. Lektura książki pozostawia jeszcze jeden niedosyt, który równie dobrze mógłby stać się postulatem. Można ją sobie bowiem z powodzeniem wyobrazić jako rozrastający się projekt w szerszy sposób redefiniujący dyskurs wojenny. Są miejsca, w których mocno osadzone w binarnej perspektywie tezy autorki domagają się uzupełnień. Teza o osobności języka Miłosza w kontekście powstańczych narracji przywołuje wymienionych w zakończeniu Mirona Białoszewskiego i Annę Świrszczyńską (czytanej przecież przez poetę) lub niewymienionego w ogóle Jerzego Ficowskiego. Żywy spór z poetami „Sztuki i Narodu” pozostawia pytanie o wzmiankowanego jedynie Krzysztofa Kamila Baczyńskiego i nieuwzględnienie jego perspektywy. Powracający binarny podział pomiędzy frazą Herberta a Miłosza oświetla puste miejsce po Różewiczu i brak reprezentacji dla niereligijnego języka w opowieści o wojnie.

\section{Bibliografia}

Grudzińska-Gross I., Miłosz i długi cień wojny, Sejny 2020.

Janicka E., Obserwatorzy uczestniczący zamiast świadków i rama zamiast obrzeży.

O nowe kategorie polskiego opisu Zagłady, „Teksty Drugie” 2018, nr 3.

Miłosz i Miłosz, red. A. Fiut, A. Grabowski i Ł. Tischner, Kraków 2013.

Rybicka E., Homo geographicus. Miłosz topografie $i$ autobiografie (rekonesans),

[w:] Czesława Miłosza strona północna, red. K. Szalewska, M. Czermińska, Gdańsk 2011.

Warszawa Miłosza, red. M. Zaleski, Warszawa 2013. 
隆 